\title{
A review of clinically suspected sepsis and meningitis in infants under 90 days old in a tertiary care center in Saudi Arabia
}

\author{
Elham Essa Bukhari, Abdulkarim Abdullah Alrabiaah \\ Department of Pediatrics, College of Medicine and King Khalid University Hospital, King Saud University, Riyadh, Kingdom of
} Saudi Arabia

\begin{abstract}
Objectives: Infections in infants $<90$ days old are the leading cause of morbidity and hospitalization in neonatal practice. The etiological agents of sepsis (with or without meningitis) in Saudi neonates $<90$ days old are vastly undercharacterized. The aim of this study was to determine the bacterial etiology of neonatal sepsis and meningitis in these infants.
\end{abstract}

Materials and methods: This retrospective study was conducted in King Khalid University Hospital, Riyadh, in the period from January 2007 to January 2011. All infants $<90$ days old with suspected sepsis during this period were examined for evidence of infection. Cultures, including blood and Cerebrospinal fluid (CSF) were performed for all neonates.

Results: A total of 304 cases of sepsis in infants $<90$ days were investigated. Community-acquired neonatal sepsis composed 284 of the studied cases present after the age of one month, while 20 infants were identified as having neonatal sepsis in the first month of life. Only 12 blood cultures were positive (four isolates of Staphylococcus epidermidis, two Staphylococcus aureus, two Staphylococcus hominis, one Enterobacter cloacae, one group B streptococcus, one diphtheroids and one with Bacillus species). Only three cases yielded positive CSF cultures. The first of these was positive for Aeromonas hydrophila, the second for Clostridium tertium and the third for Escherichia coli.

Conclusion: Suspected sepsis in infants $<90$ days old is relatively common in this hospital, with 304 cases in a four-year period. However, positive bacterial cultures were rare, constituting only $5 \%$ of the suspected cases. J Microbiol Infect Dis 2011; 1 (2) : 47-52

Key words: Children, sepsis, meningitis, tertiary center

\section{Suudi Arabistan'da bir üçüncü basamak hastanede klinik olarak sepsis ve menenjit şüpheli 90 günden küçük bebeklerin değerlendirilmesi}

ÖZET

Amaç: Doksan günden küçük bebeklerde enfeksiyonlar en önemli morbidite ve hastaneye yatırma nedenidir. Suudi Arabistan'da yenidoğanlarda menenjitle birlikte veya tek başına olan sepsisin etkenleri büyük oranda belirlenmemiştir. Bu çalışmanın amacı bu bebeklerde görülen yenidoğan sepsisi ve menenjitinin bakteriyolojik etyolojisini belirlemektir.

Gereç ve yöntem: Bu çalışma Riyad'da Kral Halid Üniversite Hastanesi'nde Ocak 2007 ile Ocak 2011 tarihleri arasında retrospektif olarak yapıldı. Çalışma süresi içinde sepsis şüphesi olan 90 günden küçük bütün bebekler enfeksiyon bulguları açısından değerlendirildi. Kan ve beyin omurilik sıvısı (BOS) kültürleri bütün bebeklerde yapıldı.

Bulgular: Toplam olarak 304 klinik sepsisli bebek araştıııldı. Toplum kaynaklı sepsis olgularının 284'ü $(\% 93,4)$ bir aydan büyük iken geri kalan 20 olgu (\% 6,6) hayatın ilk ayında hastaneye başvurmuştu. Olgulardan sadece 12'sinde (\% 4,0) kan kültürü pozitif idi (dört St. (dört Staphylococcus epidermidis izolatı, iki Staphylococcus aureus, iki Staphylococcus hominis, bir Enterobacter cloacae, bir group B streptococcus, bir diphtheroids ve bir Bacillus species izolatı). Sadece üç BOS kültüründe üreme oldu (1,0\%). Bunlardan biri Aeromonas hydrophila, biri Clostridium tertium ve biri de Escherichia coli idi.

Sonuç: Bu hastanede 90 günden küçük bebeklerde sepsis şüphesi dört yılda 304 olgu ile göreceli olarak yaygın bulundu. Buna karşııı bakteriyel kültürler şüphelenilen olguların sadece \% 5 kadarında pozitif idi.

Anahtar kelimeler: Çocuklar, sepsis, menenjit, üçüncü basamak merkez

Correspondence: Elham Essa Bukhari, Department of Pediatrics, College of Medicine and King Khalid University Hospital, King Saud University, P.O. Box 2925, Riyadh 11461 (39), Kingdom of Saudi Arabia, Email: ebukhari@yahoo.com

Received: 12.09.2011, Accepted: 29.09.2011

Copyright (c) Journal of Microbiology and Infectious Diseases 2011, All rights reserved 


\section{INTRODUCTION}

Neonatal infections are estimated to cause 1.6 million deaths every year globally, and $40 \%$ of all neonatal deaths occur in developing countries. ${ }^{1}$ The young infants with suspected sepsis are at risk for serious bacterial infections, and sepsis continues to be a significant cause of morbidity and mortality. ${ }^{2}$ There are only a few studies focusing on sepsis in infants $<90$ days old in developing countries. In these few studies, it has been documented that sepsis is the most common cause of neonatal hospitalization.3, but the etiological agents of neonatal sepsis in Saudi Arabia are unknown. The aims of this study was to determine the etiology of suspected neonatal sepsis with or without meningitis in Saudi infants $<90$ days old.

\section{MATERIALS AND METHODS}

This retrospective study was conducted between January 2007 and January 2011 in a tertiary care hospital in Riyadh, Saudi Arabia. The charts of all infants $<90$ days admitted with the diagnosis of suspected neonatal sepsis were reviewed.

- Inclusion criteria: Any infant below 90 days who presented with clinical features suggestive of sepsis.

- Exclusion criteria: Any infant with serious underlying disease like inborn error of metabolism, neurological disorder, etc.

All neonates who met this criterion were examined for evidence of infection; this investigation included blood, urine and CSF cultures. Blood for bacterial culture was collected aseptically, and $2 \mathrm{~mL}$ of blood was added to each of two bottles, one containing $20 \mathrm{~mL}$ of tryptone soy broth and the other containing $20 \mathrm{~mL}$ of bile broth. Both bottles were incubated aerobically at $37^{\circ} \mathrm{C}$ for seven days.

Gram-positive isolates were identified to the species level by conventional biochemical and serological tests. Antibiotic susceptibility was determined by the disc-diffusion method using impregnated antibiotic discs. CSF specimens were prepared for microscopic examination by cytocentrifugation (Cytospin 3; Shandon Scientific Limited, Cheshire, England) of $0.25 \mathrm{ml}$ of CSF onto a glass microscope slide at 2,000 rpm for $10 \mathrm{~min}$ at room temperature. After conventional Gram staining, slides were examined by light mi- croscopy at $\times 100$ magnification to allow quantitation of WBC and then at $\times 1,000$ magnification under immersion oil. The presence and morphology of organisms were noted. WBC were roughly quantified as none $(0 /$ slide), rare $(<10 /$ slide $)$, few (<1/oil immersion field [OIF]), moderate (1 to 10/ OIF), or many (>10/OIF). By laboratory policy, all CSF Gram stains showing organisms and/or at least moderate WBC were reviewed by senior staff. For culture, $0.15 \mathrm{ml}$ of uncentrifuged CSF specimen was inoculated onto each of one $5 \%$ sheep blood plate and one chocolate agar plate (Becton Dickinson Microbiology Systems, Cockeysville, Md.), and $1.0 \mathrm{ml}$ was inoculated into $5 \mathrm{ml}$ of brain heart infusion broth with $\mathrm{X}$ and $\mathrm{V}$ factors (Carr Scarborough Microbiologicals, Inc., Decatur, Ga.). Agar plates were incubated at $35^{\circ} \mathrm{C}$ in $5 \%$ carbon dioxide and examined daily for 3 days. Broth cultures were incubated at $35^{\circ} \mathrm{C}$ and examined daily for 7 days.

\section{Definitions}

Suspected community acquired sepsis : Infants who, after 72 hours of life, manifested systemic signs like chest retractions, grunting, abdominal distension, increased incidence of pre-feed aspiration, tachycardia, hypothermia, lethargy, apnea and other symptoms, particularly when symptoms were not explained by other illnesses. ${ }^{2}$ Confirmed sepsis: Infants with clinical features of sepsis and positive blood cultures were classified as confirmed sepsis.

There was no standard antibiotic treatment for suspected sepsis at our institution; some patients received ampicillin and gentamicin, and others were treated with ampicillin and cefotaxime.

Data were entered with Database 111 and Epi-Info software; analysis was conducted with SAS statistical software.

\section{Ethical clearance}

The study was approved by the Institutional Review Board of College of Medicine at King Saud University. The study was done according to the principles of Helsinki Declaration.

\section{RESULTS}

In total, 304 cases with clinically suspected sepsis were investigated. Of those cases, 284 were identified as having community-acquired sepsis 
presented after 30 days of life, and 20 cases hospitalized in the first month of life.

The clinical presentations of sepsis were nonspecific; the majority of patients (223) presented with fever, and $84(37 \%)$ presented with lethargy and refusal to suck. Only two patients had histories of maternal fever (about two weeks prior to delivery), and one of these two had a history of GBS; 13 patients were premature ( $<36$ weeks).

There were 12 cases with positive cultures. Among the pathogenic bacteria isolated, the most common were coagulase-negative staphylococci (CONS) $(4 / 12,30 \%)$, followed by Staphylococcus aureus $(2 / 12,15 \%)$, two cases $(2 / 12,15 \%)$ of Staphylococcus hominis, one isolate of Enterobacter cloacae, one isolate of group B streptococcus (GBS), one isolate of diphtheroid and one with Bacillus species.
Of the pathogens implicated in community acquired sepsis in infants $<90$ days, almost $66 \%$ were low-pathogenic environmental bacteria-like CONS, which also can be considerd as environmental contaminants.

All the CONS isolates were resistant to common antibiotics such as penicillin, erythromycin and cefazolin. The two isolates of Staphylococcus aureus were sensitive to methicillin and cephradine. The only Gram-negative isolate (E. cloacae) was multi-drug-resistant. It was sensitive to only two antibiotics (carbapenems and pipracillintazobactam), but was resistant to cephalosporin and aminoglycosides. There was only a single case due to infection with GBS (Table 1).

There were only 3 cases of meningitis among the 304 cases with suspected neonatal sepsis; those cases and their clinical presentations are sumarized in (Table 2).

Table 1. Positive Blood culture \& susceptibility test of clinically suspected cases of neonatal sepsis

\begin{tabular}{|c|c|c|c|c|c|}
\hline No. & Age \& sex & Blood culture & $\begin{array}{l}\text { Antibiotic susceptibility } \\
\text { test sensitive }\end{array}$ & Clinical features & Treatment \\
\hline 1 & 7 days & S.aureus & Methicillin-Cephradine & Fever + refuse to suck & $\begin{array}{c}\text { Cloxacillin + Gentamicin } \\
\text { Vancomycin }\end{array}$ \\
\hline 2 & 4days & S.epidermidis & Vancomycin & Fever & Ampicillin + Gentamicin \\
\hline 3 & 38 days & S.epidermidis & Vancomycin & Fever + vomiting & Ampicillin + Gentamicin \\
\hline 4 & 45 days & Enterobacter cloacae & Piperacillin tazobactam & Fever & Meropenem + Amikacin \\
\hline 5 & 13 days & S.aureus & Methicillin & Irritable & $\begin{array}{c}\text { Ampicillin + cefototaxime } \\
\rightarrow \text { Cloxacillin }\end{array}$ \\
\hline 6 & 10 days & Bacillus species & - & Foul smell from umbilicus & Cloxacillin \\
\hline 7 & 41 days $M$ & S. hominis & - & Fever x 1day & Ampicillin + Cefotaxime \\
\hline 8 & 3 days $F$ & Group B Streptococcus & $\begin{array}{l}\text { Vancomycin } \\
\text { Ceftrixone } \\
\text { Penicillin }\end{array}$ & Fever $x$ 1day & Ampicillin + gentamicin \\
\hline 9 & 10 days $F$ & S.epidermidis & Vancomycin & Fever & Ampicillin + Gentamicin \\
\hline 10 & 43 days $F$ & S.hominis & $\begin{array}{l}\text { Vancomycin } \\
\text { Cloxacillin }\end{array}$ & Fever + refuse to suck & Ceftrixone \\
\hline 11 & 19 days $F$ & S.epidermidis & $\begin{array}{l}\text { Vancomycin } \\
\text { Clindamycin }\end{array}$ & $\begin{array}{l}\text { Fever } \mathrm{x} 1 \text { day } \\
\text { Well }\end{array}$ & Ampicillin + Gentamicin \\
\hline 12 & 35 days $F$ & Diphtheroids & - & Fever & Ampicillin, Cefotaxime \\
\hline
\end{tabular}


Table 2. Positive CSF culture and antibiotic sensitivity in cases of suspected meningitis

\begin{tabular}{|c|c|c|c|c|c|c|c|}
\hline \multirow[t]{2}{*}{ No. } & \multirow[t]{2}{*}{ Age } & \multirow[t]{2}{*}{ Culture } & \multicolumn{2}{|c|}{ Sensitivity } & \multirow[t]{2}{*}{ Clinical features } & \multirow[t]{2}{*}{ Treatment } & \multirow[t]{2}{*}{ Duration } \\
\hline & & & Sensitive & Resistant & & & \\
\hline 1 & 30 days & Aeromonas hydrophila & $\begin{array}{l}\text { Aztreonam Cefradine } \\
\text { Clprofloxacin } \\
\text { Cefuroxime }\end{array}$ & $\begin{array}{l}\text { Ceftazdime } \\
\text { Ceftrixone }\end{array}$ & $\begin{array}{l}\text { Febrile+ irritable } \\
\text { Refuses to suck }\end{array}$ & $\begin{array}{l}\text { Ampicillin + } \\
\text { cefotaxime } \\
\text { Cefotaxime } \\
\text { Gentamicin }\end{array}$ & 14days \\
\hline 2 & 40 days & Clostridum tertium & $\begin{array}{l}\text { Penicillin } \\
\text { Cefotaxime } \\
\text { Cetazidime }\end{array}$ & & $\begin{array}{l}\text { III - febrile + } \\
\text { refuses to suck }\end{array}$ & $\begin{array}{l}\text { Ampicillin + } \\
\text { ceftazidime }\end{array}$ & 25 days + ICU \\
\hline 3 & 60 days & Escherichia coli & $\begin{array}{c}\text { Gentamicin } \\
\text { Cefotaxime } \\
\text { Ampicillin }\end{array}$ & & $\begin{array}{c}\text { Febrile + } \\
\text { refuses to suck }\end{array}$ & Ceftrixone & 21 days \\
\hline
\end{tabular}

The first case of meningitis was a 30 dayold-male with a positive culture for Aeromonas hydrophila who was treated with Ampicillin and Cefotaxime for three weeks. Clostridium tertium was isolated from the CSF of the second case, a 4-day-old male infant. He was treated with Ampicillin and Ceftazidime for three weeks. The third case was 60-day old-male infant; $E$. coli was isolated from his CSF. He was given intravenous Ceftriaxone for 21 days.

None of these patients had positive blood cultures, and all patients recovered without neurological sequelae.

\section{DISCUSSION}

Neonatal sepsis remains a major cause of mortality and morbidity in newborns. It is one of the most common causes of neonatal hospital admissions. ${ }^{1-3}$ Early-onset sepsis (EOS): Infants who manifested with systemic signs of sepsis within the first 72 hrs of life were classed as having EOS. EOS is conventionally assumed to be maternally acquired, with causative organisms, such as E. coli and GBS that are usually found in the maternal genital tract. Late onset sepsis (LOS) is usually considered to be environmental in origin (either hospital or community-acquired) in infants with clinical features of sepsis after 72 hours of life.

A knowledge of pathogens causing infections in young infants ( $<90$ days old) is essential for devising community-based management strategies. Most studies worldwide focus on neonatal sepsis in premature babies admitted to intensive care units, and a few studies discuss only those infants $<90$ days old suspected to have neonatal sepsis who required admission to a general pediatric ward.

Recent studies on neonatal sepsis in developed countries note that the organism profile has changed significantly, with a reduction in Gramnegative bacteria, an increase in sepsis related to $S$. aureus and the emergence of new organisms, such as non-fermentative Gram-negative bacteria. ${ }^{2-3}$ Data on recent trends in species causing sepsis in infants $<90$ days of life developing countries are limited. ${ }^{3}$ Zhu et al. reported a pattern of organisms similar to those discovered in our study. The pathogens identified in 80 cases of late-onset neonatal sepsis were Staphylococcus species (CONS in 50 cases), followed in frequency by Escherichia coli. The most important pathogen in cases of hospital-acquired LOS was Klebsiella pneumoniae. ${ }^{4}$ Sundaram et al. conducted their study in a tertiary care neonatal unit in Northern India and found, surprisingly, that the incidence of bacterial sepsis has decreased significantly in infants who weigh 1000 to $1999 \mathrm{gr}$. Meanwhile, new agents have emerged in recent years, resulting in an increase in the incidence of $S$. aureus and $S$. epidermidis infections and a decrease in the incidence of Klebsiella pneumoniae and Enterobacter aerogenes infections. The reason for this drift is not clearly understood. ${ }^{1}$

In another study from Nigeria, 198 neonates were screened for sepsis, yielding 61 positive blood cultures. Gram-negative bacilli were the most common organisms in 10 isolates from EOS, while S. aureus (38.8\%) and CONS (22.6\%) were the most common causes of LOS (from a total of 51 isolates) ${ }^{5}$ 
Other studies have found different organisms responsible for neonatal sepsis and neonatal meningitis. One study in the Philippines of 873 infants cultured bacteria from the blood of only 35 infants; after the exclusion of presumed contaminants, Salmonella spp. (6) were the most common, followed in decreasing order of prevalence by Enterobacter spp. (3), other Gram-negative organisms (8), Gram-positive organisms like Streptococcus pyogenes (3), Streptococcus pneumoniae (1) and $S$. aureus (2). The most common CSF isolates were Gram-negative organisms, specifically Acinetobacter spp. (4 cases), Escherichia coli (2 cases) and one instance each of Pseudomonas aeruginosa, Enterobacter cloacae and Hemophilus influenzae type B. There was no clear explanation of this result of bacterial findings in this study. ${ }^{7}$

There is considerable variation in the etiology of LOS worldwide, particularly between developing and developed countries in Latin America, Southeast Asia, and Middle East. These regions have reported high rates of CONS infections, which may indicate high rate of invasive device use. . $^{8-10}$

In our study, we isolated only three organisms from the CSF; the small number of meningitis cases may be indicative of the low incidence of meningitis in community-acquired sepsis. Moreover, the CSF isolates A. hydrophila and C. tertium are atypical agents of neonatal meningitis.

Surprisingly, the etiologic agent of suspected sepsis in infants $<90$ days old in our institution could only rarely be isolated; most of which were contaminant organisms, in contrast to the findings of other studies performed in developing countries. ${ }^{11-15}$

The dominance of $S$. aureus and CONS may be explained by the tendency of $S$. aureus to colonize the skin, nasopharynx, and gastrointestinal tract and spread via the hands of health care workers. ${ }^{16}$ The reason for the low number of culture-positive cases found in our study is not clearly understood, but it may be a consequence of aggressive clinical management of infants presenting with apparent sepsis. We should most likely consider conservative management strategies based on laboratory and clinical criteria for infants without apparent sepsis.

In conclusion, contrary to our expectations, the findings of this study are that positive culture results from clinically suspected cases of sepsis and meningitis are uncommon in the population studied. However, it is very important to regularly re-evaluate the standard antimicrobial therapy for neonatal sepsis, particularly in managing LOS.

Pediatricians in the emergency room should be restricted to following clinical practice guidelines for the management of suspected cases of neonatal sepsis, and they should follow the local guidelines derived from institutional blood culture results. In view of the limitation of this study since it is a retrospective one, prospective studies should be carried on to obtain accurate information. Furthermore, future studies should focus on EOS, LOS and meningitis in this region.

\section{REFERENCES}

1. Sundaram V, Kumar P, Dutta S. Blood culture confirmed bacterial sepsis in neonates in a North Indian tertiary care center: changes over the last decade. Jpn J Infect Dis 2009; 62:46-50.

2. Sankar MJ, Agarwal R, Jeevasankar M. Sepsis in the newborn. Indian J Pediat 2008; 75:261-272.

3. Darmstadt G, Batra M, Zaidi A. Parental antibiotics for the treatment of serious neonatal bacterial infections in developing country communities. Pediatric infect Dis J 2009; 28: S37 - S42.

4. Zhu ML, Zheng G, Chen JN, Lin ZL, Zhu JH, Lin J. Comparative analysis of the pathogens responsible for hospital acquired and community acquired late onset neonatal septicemia. Zhonghua Er Ke Za Zhi 2008; 46: 124-127.

5. Mokuolu AO, Jiya N, Adesiyun OO. Neonatal septicaemia in Ilorin: bacterial pathogens and antibiotic sensitivity pattern. Afr J Med Sci 2002; 31:127-130.

6. Zaidi A, Thaver D, Alos, Khan A. Pathogens Associated with sepsis in Newborns and young infants in Developing countries. Pediatric Infect Dis J 2009; 28 S10-S18.

7. Gatchalian S, Quiambao B, Morelos A. Bacterial and viral etiology of serious infections in very young Filipino infants. Pediatric Infect Dis J 1999; 18:50-55.

8. Viswanathan R, Singh AK, Mukherjee S, Mukherjee, Das P, Basu S. Aetiology and Antimicrobial Resistance of Neonatal Sepsis at a Tertiary Care Centre in Eastern India: A 3 Year Study. Indian J Pediatr 2010; 17:300-304.

9. Baraff LJ. Management of infants and young children with fever without source. Pediatr Ann 2008; 37:673-679.

10. Zaidi AKM, Huskins WC, Thaver,D, et al.: Hospital acquired neonatal infections in developing countries. Lancet 2005;365:1175-1188.

11. Osrin D, Vernanos, Costello A. Serious bacterial infections in newborn infants in developing countries. Curr Opin Infect Dis 2004; 17:217-24.

12. Ben Humida NE, Harouni M, Chaonachis Sfar R, Marrakchi Z. Early onset neonatal bacterial infections: A series of 144 cases. Tunis Med 2008; 86:136-139.

13. Nandyal RR. Update on group B streptococcal infections: perinatal and neonatal periods. J Perinat Neonatal Nurs 2008; 22:230-237. 
14. Chirico G, Cortinouis S, Fonte C, Giudicig Bacterial sepsis. J Chemotherapy 2007; 19:S28-30.

15. Arnon S, Litmanovitz I. Diagnostic tests in neonatal sepsis. Curr Opin Infect Dis 2008; 21: 223-227.
16. Thaver D, Zaidi A. Burden of Neonatal Infections in developing countries: A Review of Evidence from Community Based Studies, Pediatric infect Dis J 2009;28: S3-S9. 